\title{
Comparison of polymerase chain reaction and bacterial culture for Salmonella detection in the Muscovy duck in Trinidad and Tobago
}

\author{
Joanne Rampersad, ${ }^{1,2}$ Jenelle Johnson, ${ }^{3}$ Gabriel Brown, ${ }^{3}$ \\ Michael Samlal, ${ }^{3}$ and David Ammons ${ }^{1,2}$
}

Suggested citation

Rampersad J, Johnson J, Brown G, Samlal M, Ammons D. Comparison of polymerase chain reaction and bacterial culture for Salmonella detection in the Muscovy duck in Trinidad and Tobago. Rev Panam Salud Publica. 2008;23(4):264-7.

\begin{abstract}
Objectives. The purpose of this study was to investigate the presence and serovar identity of Salmonella, at the national level, in farmed Muscovy ducks (Cairina moschata) in Trinidad and Tobago, and to compare the relative benefits of bacterial culture to those of polymerase chain reaction (PCR) for use in the routine detection and surveillance of Salmonella in these ducks. Methods. From March-September 2003, 110 fecal samples were collected from 82 farms across the islands of Trinidad and Tobago. Salmonella was isolated from fresh and frozen samples and the serotype of each was determined through bacterial culture. An in-house, nested PCR that detects all pathogenic Salmonella species was utilized in analyzing the samples.

Results. Five samples were positive for Salmonella by bacterial culture, whereas 44 were positive by the nested PCR. Serovars isolated were Kiambu, Orion, Uganda, and two isolates from Group E1 whose H antigens could not be fully characterized. Of the samples, 87 (79\%) gave equivalent PCR results for both enrichment broths-28 were positive for both and 59 were negative for both). However, 16 samples were positive for one broth, but not for the other, with the majority (14 of the 16) resulting positive for Selenite broth. PCR results for seven samples were inconclusive due to ambiguous band size or multiple bands near the expected band size. Conclusions. In Trinidad and Tobago, the Muscovy duck does not appear to be a significant source of $S$. typhimurium or S. enteritidis, but it does harbor other Salmonella species. In-house, nested PCR represents a simple, relatively inexpensive and potentially more sensitive method than bacterial culture for the routine surveillance of pathogenic Salmonella in the Muscovy duck.
\end{abstract}

Key words Polymerase chain reaction, Salmonella, Trinidad and Tobago.

Serovars of the bacterium Salmonella enterica ssp. enterica are known to be a

1 University of Texas-Pan American, Department of Chemistry, Edinburg, Texas, United States of America. Send correspondence to: David Ammons, 1200 West University Drive, Edinburg, TX, 78539, USA; telephone: +01-956-381-2097; fax: +01956-384-5006; email: ammonstt@hotmail.com.

2 Department of Life Sciences, the University of the West Indies, St. Augustine, Trinidad and Tobago.

3 School of Veterinary Medicine, the University of the West Indies, Mt. Hope, Trinidad and Tobago. significant cause of foodborne illness in humans. It is well established that different serovars can be associated with different animals-e.g., S. Enteritidis in poultry-which act as a source of foodborne infection in humans (1). The current strategy for food safety is one that starts on the farm. The "Food Safety from Farm to Table" initiative of the United States Food and Drug
Administration's Center for Food Safety and Applied Nutrition (2) and the European Union's "Farm to Fork" integrated approach (3) are two such strategies that underscore the importance of detecting Salmonella in food animals at the farm level.

The Muscovy duck (Cairina moschata), and its hybrid mules, are relatively large, hardy birds, raised globally for 
their high quality, relatively low-fat meat. In Trinidad and Tobago and other tropical developing countries, these birds are commonly raised on smallscale farms or allowed to roam free in the yard. However, unlike chickens, the prevalence of specific Salmonella serovars associated with these birds is not well characterized and the potential role of these ducks as a source of infection in humans is mostly unknown (4). In Trinidad and Tobago, very little is known about Salmonella infection in the duck, except that records from the Government's Veterinary Laboratory and the University of the West Indies School of Veterinary Medicine show that from 1973-2004 Salmonella serovars, including $S$. Typhimurium and $S$. Enteritidis, have been isolated from ducks. ${ }^{4} \mathrm{Al}-$ though there is a need to monitor farmed ducks for the presence of Salmonella, the cost and complexity of this screening can be demanding and may not be feasible, especially for developing countries with limited resources. Therefore, the purpose of this study was to investigate the presence and serovar identity of Salmonella at the national level in farmed Muscovy ducks in Trinidad and Tobago, and to compare the relative benefits of bacterial culture and polymerase chain reaction (PCR) for use in the routine detection and surveillance of Salmonella in these ducks.

\section{MATERIALS AND METHODS}

\section{Sample collection}

From March-September 2003, fecal samples were collected at small-scale and "backyard" farms with approximately one to five pens containing approximately 20-50 birds/pen. A total of 110 fecal samples were collected from 86 farms comprising an approximately equal number of farms from each of the

\footnotetext{
4 Brown G. Presence of Salmonella in avian species in Trinidad and Tobago. Complied from records dated from 1973-2004 maintained by the Government of Trinidad and Tobago's Veterinary Laboratory and the University of the West Indies School of Veterinary Medicine. Contact: Dr. Gabriel Brown, School of Veterinary Medicine, The University of the West Indies, Trinidad and Tobago; email: gbrown@fms.uwi.tt
}

eight counties in Trinidad and the island of Tobago. When farms were found to contain multiple, physically separate duck pens, more than one pen per farm was at times sampled. Each fecal sample comprised a mixture of five freshly collected fecal specimens from a single pen. Samples were placed on ice and transported to the laboratory for processing.

\section{Culture and isolation}

In the laboratory, each sample tube containing five fecal specimens was homogenized by mixing with a toothpick, then a pea-sized amount removed to Selenite broth for culture at $37^{\circ} \mathrm{C}$ for 24 hours, after which an aliquot was streaked on a Xylose Lysine Desoxycholate (XLD) plate and evaluated as described below. The remaining fecal sample was frozen at $-70^{\circ} \mathrm{C}$ in $10 \%$ glycerol.

Culture and PCR of frozen stocks was performed from March-April 2006. A sterile toothpick was used to remove a pea-sized aliquot of the frozen sample to a tube containing $500 \mu \mathrm{l}$ of peptone water, incubated for 6 hours at $28^{\circ} \mathrm{C}$, after which a $250 \mu$ l sample was used to inoculate $5 \mathrm{~mL}$ of Rappaport-Vassiliadis (RV) and Selenite broths, and incubated 24 hours at $37^{\circ} \mathrm{C}$. After 24 hours, the RV and Selenite broths were streaked on both XLD and Brilliant Green Agar (BGA) agars and incubated 24 hours at $37^{\circ} \mathrm{C}$. Suspect colonies from the agar medias were subjected to biochemical testing, where isolates showing alkaline/acid, $\mathrm{H}_{2} \mathrm{~S}$, no gas on Triple Sugar Iron (TSI) slants, urease-negative, and alkaline/alkaline on Lysine Iron Agar (LIA) were sent to the Caribbean Epidemiological Center (CAREC), Trinidad, for serological typing.

\section{Template preparation}

A $100 \mu \mathrm{l}$ aliquot of the same overnight culture of RV and Selenite broths used for culture on XLD and BGA agars was removed and spun at approximately $12000 \mathrm{rpm}$ for 30 seconds in a $1.5 \mathrm{~mL}$ microcentrifuge tube, the supernatant was removed and the pellet washed with $100 \mu$ l of sterile, dis- tilled water and spun as before. The pellet was resuspended in $40 \mu \mathrm{l}$ of water and $1 \mu \mathrm{l}$ was used in PCR reactions. For Salmonella isolated from duck feces, a small amount of a bacterial colony grown on XLD agar was used directly in the PCR.

\section{Polymerase chain reaction}

Primers out139 (5'-ctggcattatcgatcagtacc-3') and out141 (5'-ataaacttcatcgcaccgtc-3') were designed for this project and produced a $344 \mathrm{bp}$ amplicon in the primary reaction. For the nested reaction, primers 139 and 141 produced a 285 bp amplicon, and have been described elsewhere (5) and shown to be effective for the detection of pathogenic Salmonella (6). Reaction conditions were optimized in an Eppendorpf Mastercycler Gradient (Eppendorf North America, Westbury, New York, United States) using a temperature gradient from $45^{\circ} \mathrm{C}-65^{\circ} \mathrm{C}$ at 15,20 , and $30 \mathrm{mM} \mathrm{MgCl}{ }_{2}$. PCR conditions for the primary reaction were $0.5 \mathrm{mM}$ each primer, $3 \mathrm{mM} \mathrm{MgCl}$, $0.2 \mathrm{mM}$ each $\mathrm{dNTP}$, and approximately 0.5 units of Taq polymerase. Cycle conditions were $94^{\circ} \mathrm{C}$ for 15 seconds, $63^{\circ} \mathrm{C}$ for 30 seconds, and $72^{\circ} \mathrm{C}$ for 45 seconds for a total of 40 cycles, followed by incubation at $72^{\circ} \mathrm{C}$ for 5 minutes. PCR conditions for the nested reaction were $0.5 \mathrm{mM}$ of each primer, $2 \mathrm{mM} \mathrm{MgCl}_{2}$, $0.2 \mathrm{mM}$ each dNTP, approximately 0.5 units of Taq polymerase, and $1 \mu \mathrm{l}$ of the primary reaction as template. Cycle conditions were $94^{\circ} \mathrm{C}$ for 15 seconds, $60^{\circ} \mathrm{C}$ for 30 seconds, and $72^{\circ} \mathrm{C}$ for 45 seconds for a total of 40 cycles, followed by incubation at $72^{\circ} \mathrm{C}$ for 5 minutes. Amplicons in $15 \mu \mathrm{l}$ of each PCR reaction were separated by size on a $2 \%$ agarose gel, stained with ethidium bromide and visualized under UV light. PCR analysis was performed on broth inoculated with frozen samples and not fresh samples.

Controls for false-positive reactions were performed along with all samples processed and analyzed by PCR. To control for false-positive reactions due to contaminating DNA in the PCR reagents, PCR reactions were performed without the addition of DNA 
template. To control for false-positive reactions due to contaminating DNA in the prepared template, uninoculated tubes of Selenite and Rappaport-Vassiliadis broths were incubated, processed, and subjected to PCR analysis along with, and in the same manner as, the fecal samples. To further aid in the control of false-positive reactions due to contaminating DNAs, sample preparation, the transfer of template to nested reactions, and gel electrophoresis were each performed in separate rooms, wherein the transfer of template for nested reactions was also performed in a UV sterilized hood.

\section{RESULTS}

\section{Culture and PCR}

Salmonella was isolated from three samples when cultured directly into Selenite broth (serovars Kiambu and Uganda) and from three samples after being frozen (serovar Orion and Group E1 whose complete $\mathrm{H}$ antigen profile could not be determined). The Group E1 isolates were reported by CAREC as possibly not having been previously reported in Trinidad and Tobago, and were therefore sent to a reference lab for further characterization. Only one sample was positive by culture for Salmonella in both the pre- and postfreezing cultures, however the serovars differed; all Salmonella isolates were positive by PCR (Table 1).

Of 110 frozen fecal samples preenriched in peptone and then cultured in both Selenite and RV broths and tested for the presence of Salmonella by nested PCR, 87 (79\%) gave equivalent results for both culture medias (28 were both positive and 59 were both negative). Sixteen samples were positive for one broth but not the other, and of these, the majority $(14 / 16)$ were positive for Selenite. Seven samples gave inconclusive results.

\section{DISCUSSION}

In this work, pooled fecal samples were used in order to better assess the

TABLE 1. Polymerase chain reaction (PCR) and bacterial culture of Salmonella isolates from duck fecal samples, Trinidad and Tobago, March-September 2003

\begin{tabular}{|c|c|c|c|c|c|c|}
\hline Sample state & $\begin{array}{c}\text { Sample } \\
\text { No. }\end{array}$ & Culture broth & $\begin{array}{l}\text { Isolation } \\
\text { agar }\end{array}$ & $\begin{array}{l}\text { Isolate } \\
\text { serovar }\end{array}$ & $\begin{array}{c}\text { PCR of } \\
\text { broth }\end{array}$ & $\begin{array}{l}\text { PCR of } \\
\text { isolate }\end{array}$ \\
\hline Fresh & 61 & Selenite & $X L D^{a}$ & Uganda & $N P^{b}$ & + \\
\hline Fresh & 7 & Selenite & XLD & Kiambu & NP & + \\
\hline Fresh & 35 & Selenite & XLD & Kiambu & NP & + \\
\hline Frozen & 4 & Selenite & XLD & Orion & $+^{c}$ & + \\
\hline Frozen & 17 & Selenite & XLD & Unknown & + & + \\
\hline Frozen & 17 & Rappaport-Vassiliadis & XLD & Unknown & + & + \\
\hline Frozen & 17 & Rappaport-Vassiliadis & $B G A^{d}$ & Unknown & + & + \\
\hline Frozen & 61 & Rappaport-Vassiliadis & XLD & Unknown & + & + \\
\hline Frozen & 61 & Rappaport-Vassiliadis & BGA & Unknown & + & + \\
\hline
\end{tabular}

\footnotetext{
a Xylose Lysine Desoxycholate.

${ }^{b}$ Not performed.

c Positive.

d Brilliant Green Agar.
}

presence of Salmonella at the flock level (7). When testing for Salmonella, it is not always desirous, or even at times possible, to collect large numbers of samples and process them the same day. Alternatively, freezing samples allows the laboratory to choose the time and number of samples to be processed, but may affect bacterial survival. Although this work did not seek to investigate the culture of fresh versus frozen samples, little difference was seen between the two in the number of salmonellae isolated by culture (each gave three samples positive for Salmonella). However, the serovars identified and the samples shown to contain Salmonella did vary between frozen and unfrozen samples. This variation, however, could have been due to factors other than freezing, such as levels of Salmonella in the samples at or near the detection level by culture.

The relatively high sensitivity of the nested PCR did identify more samples with Salmonella and most probably benefited from enrichment in selective broths (8-10). However, 16 samples did not give similar results for both broths. Contamination, specifically amplicons, could account for the differing results, however negative controls indicated that there was not any detectable contamination either in the PCR master mix, nor arising during template preparation from the broth cultures. In addition, 14 of the 16 samples giving noncongruent results were PCR positive only with Selenite broth, suggesting that Selenite broth performed better than RV broth.

Neither S. Enteritidis nor S. Typhimurium were isolated suggesting that the Muscovy duck is probably not a significant source of human infection for these serovars. Similarly, records in Trinidad and Tobago for 1990-1999 show that of 772 isolates of Salmonella originating from human infection, none were found to be $S$. Kiambu and only $17 \mathrm{~S}$. Uganda. ${ }^{5}$ Similarly, records from Trinidad and Tobago's Veterinary Laboratory for 1973-2004 indicated only 13 specimens positive for $S$. Uganda and three for $S$. Kiambu, none of which originated from ducks. ${ }^{6}$ $S$. Orion was not reported in any of the above. However, the high prevalence of Salmonella serovars in the ducks does identify them as a largely uncharacterized reservoir for Salmonella and as such should be monitored.

Although desirable, economic and time constraints associated with the routine monitoring of commercial flocks for Salmonella may preclude its practice. Consistent with results of this work, PCR can represent an alternative to costly and time consuming culture methods for the detection of pathogenic Salmonella species in a sample (11-13). In addition, pre-screening

\footnotetext{
5 Ramcharitar A, Sookoo A. A comparative study of human and animal Salmonella isolates in Trinidad and Tobago from 1990 to 1999. [Research Project] School of Veterinary Medicine, The University of the West Indies: Trinidad and Tobago; 2000.

6 Brown G.
} 
with PCR may be useful in identifying samples harboring Salmonella, and thus, reduce the number of samples subjected to either culture or further characterization by emerging PCR methods $(14,15)$. animals. CABI Publishing: New York; 2000. Pp. 107-245.

2. United States Food and Drug Administration. Food safety from farm to table. Available from: http://www.cfsan.fda.gov/ dms/ftt farm.html. Accessed 16 December 2006.

3. European Union. Farm to fork approach. Available from: http://ec.europa.eu/food/ index_en.htm. Accessed 16 December 2006.

4. Chute HL, Gershman M. Salmonella pullorum in a muscovy (Cairina moschata) duck. Avian Dis. 1963; 7(2):168-9.

5. Rahn K, De Grandis SA, Clarke RC, McEwen SA, Galán JE, Ginocchio C et al. Amplification of an invA gene sequence of Salmonella typhimurium by polymerase chain reaction as a specific method of detection of Salmonella. Mol Cell Probes. 1992; 6(4): 271-9.

6. Malorny B, Hoorfar J, Bunge C, Helmuth R. Multicenter validation of the analytical accuracy of Salmonella PCR: towards an international standard. Appl Environ Microbiol. 2003;69(1): 290-6.

7. Singer RS, Cooke CL, Maddox CW, Isaacson RE, Wallace RL. Use of pooled samples for the
Acknowledgements. The authors would like to thank the Veterinary Diagnostic Laboratory of the Government of Trinidad and Tobago for sharing data on Salmonella serovars isolated from animals, the Poultry Sur-

\section{REFERENCES}

detection of Salmonella in feces by polymerase chain reaction. J Vet Diagn Invest. 2006;18(4): 319-25.

8. Fakhr MK, McEvoy JM, Sherwood IS, Logue $\mathrm{CM}$. Adding a selective enrichment step to the iQ-Check real-time PCR improves the detection of Salmonella in naturally contaminated retail turkey meat products. Lett Appl Microbiol. 2006;43(1):78-83.

9. Myint MS, Johnson YJ, Tablante NL, Heckert RA. The effect of pre-enrichment protocol on the sensitivity and specificity of PCR for detection of naturally contaminated Salmonella in raw poultry compared to conventional culture. Food Microbiol. 2006;23(6):599-604.

10. Oliveira SD, Rodenbusch CR, Ce MC, Rocha $\mathrm{SL}$, Canal CW. Evaluation of selective and non-selective enrichment PCR procedures for Salmonella detection. Lett Appl Microbiol. 2003;36(4):217-21.

11. Malkawi HI, Gharaibeh R. Multiplex PCR for the direct detection of Salmonella enterica from chicken, lamb and beef food products. J Basic Microbiol. 2003;43(4):328-36.

12. Eyigor A, Carl, KT. Rapid detection of Salmonella from poultry by real-time polymerase veillance Unit of Trinidad and Tobago for assistance in sample collection, the Caribbean Epidemiological Center for serotyping Salmonella isolates, and the Pan American Health Organization for its financial support. chain reaction with fluorescent hybridization probes. Avian Dis. 2003;47(2):380-6.

13. Whyt P, Mc Gill K, Collins JD, Gormley E. The prevalence and PCR detection of Salmonella contamination in raw poultry. 2002; Vet Microbiol. 89(1):53-60.

14. Soumet C, Ermel G, Rose V, Rose N, Droulin $P$, Salvat $G$, Colin P. Identification by a multiplex PCR-based assay of Salmonella Typhimurium and Salmonella Enteritidis strains from environmental swabs of poultry houses. Lett Appl Microbiol. 1999;29(1):1-6.

15. Kim S, Frye JG, Hu J, Fedorka-Cray PJ, Gautom R, Boyle DS. A Multiplex PCR based Method for the Identification of common Clinical Serotypes of Salmonella enterica subspecies enterica. J Clin Microbiol. 2006;44(10): 3608-15.

Manuscript received on 2 January 2007. Revised version accepted for publication on 31 January 2008.

RESUMEN Objetivos. Investigar la presencia de Salmonella en patos criollos (Cairina moschata) criados en Trinidad y Tobago e identificar los serotipos circulantes en el país, así como comparar los beneficios relativos del cultivo bacteriano con respecto a la reacción en cadena de la polimerasa (RCP) en la detección y la vigilancia cotidianas de la Salmonella en estos patos.

Comparación de la reacción en cadena de la polimerasa y el cultivo bacteriano como métodos de detección de Salmonella en patos criollos en Trinidad y Tobago

Métodos. Entre marzo y septiembre de 2003 se tomaron 110 muestras de heces fecales de 82 granjas distribuidas por las islas de Trinidad y Tobago. Se aisló Salmonella de muestras frescas y congeladas y se determinaron los serotipos mediante el cultivo bacteriano. Se utilizó un sistema autóctono de RCP anidada que detecta todas las especies patógenas de Salmonella en las muestras.

Resultados. Cinco muestras resultaron positivas para Salmonella mediante el cultivo bacteriano, mientras que 44 fueron positivas mediante la RCP anidada. Se asilaron los serotipos Kiambu, Orion, Uganda y dos aislamientos del grupo E1, cuyos antígenos $\mathrm{H}$ no se pudieron caracterizar totalmente. Hubo coincidencia en 87 (79\%) de las muestras analizadas por RCP en ambos caldos de enriquecimiento ( 28 positivas y 59 negativas). Sin embargo, 16 muestras positivas en un caldo resultaron negativas en el otro; la mayoría de ellas (14 de 16) resultaron positivas en caldo selenito. Siete muestras resultaron indefinidas mediante la RCP debido a tallas ambiguas de las bandas o a múltiples bandas cerca de la talla esperada.

Conclusiones. El pato criollo no parece ser una fuente importante de infección por S. typhimurium y S. enteritidis en Trinidad y Tobago, aunque hospeda otras especies de Salmonella. El sistema autóctono de RCP anidada constituye un método simple, relativamente económico y posiblemente más sensible que el cultivo bacteriano en la vigilancia cotidiana de especies patógenas de Salmonella en el pato criollo.

Palabras clave Reacción en cadena de la polimerasa, Salmonella, Trinidad y Tobago. 